\title{
Adherens junctions associated protein 1 serves as a predictor of recurrence of squamous cell carcinoma of the esophagus
}

\author{
HARUYOSHI TANAKA*, MITSURO KANDA* , MASAHIKO KOIKE, NAOKI IWATA, DAI SHIMIZU, \\ KAZUHIRO EZAKA, SATOSHI SUEOKA, YURI TANAKA, HIDEKI TAKAMI, RYOJI HASHIMOTO, \\ CHIE TANAKA, SUGURU YAMADA, TSUTOMU FUJII, GORO NAKAYAMA, HIROYUKI SUGIMOTO, \\ MICHITAKA FUJIWARA and YASUHIRO KODERA
}

Department of Gastroenterological Surgery (Surgery II), Nagoya University

Graduate School of Medicine, Showa-ku, Nagoya 466-8550, Japan

Received July 7, 2015; Accepted August 19, 2015

DOI: 10.3892/ijo.2015.3167

\begin{abstract}
Esophageal squamous cell carcinoma (ESCC), the most common esophageal cancer in East Asia, is among the six cancers with the highest fatality rates worldwide. Unfortunately, multidisciplinary treatment strategies have not achieved satisfactory outcomes. Therefore, novel insights into the molecular biology of ESCC are required to improve treatment. The gene encoding the transmembrane adherens junctions-associated protein-1 (AJAPl) expressed by epithelial cells resides in chromosome $1 \mathrm{p} 36$, which is frequently lost or epigenetically silenced in several malignancies. Here, we investigated the expression levels and regulatory mechanism of AJAPI transcription. We determined the levels of $A J A P I \mathrm{mRNA}$ and the genes encoding potentially interacting proteins expressed by ESCC cell lines, as well as the chromosomal copy number of $A J A P I$ and the methylation status of its promoter region. AJAPI mRNA levels of 78 pairs of surgically resected specimens were determined to evaluate the association of $A J A P I$ expression and clinicopathological factors. Nine ESCC cell lines differentially expressed AJAP1 mRNA, and demethylation of hypermethylated AJAPI genomic DNA reactivated AJAPI mRNA expression. The copy number of sequences upstream or downstream of the AJAPI transcriptional start site was not detectably altered. AJAPI mRNA levels correlated inversely with those of ezrin (EZR) and were significantly lower in ESCC tissues compared with adjacent normal tissues. AJAPI mRNA levels decreased gradually with
\end{abstract}

Correspondence to: Dr Mitsuro Kanda, Department of Gastroenterological Surgery (Surgery II), Nagoya University Graduate School of Medicine, 65 Tsurumai-cho, Showa-ku, Nagoya 466-8550, Japan

E-mail:m-kanda@med.nagoya-u.ac.jp

*Contributed equally

Key words: esophageal cancer, AJAP1, methylation, recurrence, biomarker increasing tumor stage. Patients with downregulated AJAPI transcription were more likely to experience shorter overall and disease-free survival. Multivariate analysis of disease-free survival identified downregulated $A J A P 1$ transcription as an independent prognostic factor. These results suggest that in ESCC, AJAP1 acts as a putative tumor suppressor and that $A J A P 1$ transcription is regulated by promoter hypermethylation. These findings indicate that downregulated AJAPI transcription may serve as a novel tumor biomarker to predict recurrence of ESCC after esophagectomy.

\section{Introduction}

Esophageal cancer ranks sixth among all cancers in mortality worldwide because of its extremely aggressive nature $(1,2)$. The predominant histological types of esophageal cancer are adenocarcinoma and squamous cell carcinoma (3). Adenocarcinoma of the distal esophagus predominates in Western countries, whereas esophageal squamous cell carcinoma (ESCC) predominates in Asia (3). The mechanism of carcinogenesis of ESCC differs from that of adenocarcinoma, which has been widely studied in North America and Europe (3). Further, exogenous factors such as smoking, drinking, nitrosamines, and consumption of hot beverages correlate significantly with the development of ESCC but not with adenocarcinoma of the esophagus $(4,5)$. Recent advances in our understanding of the molecular biology of ESCC document the role of genetic alterations in tumorigenesis $(6,7)$. Therefore, a better understanding of the molecular mechanisms of progression and recurrence is of paramount importance, and identification of the genes that mediate ESCC pathogenesis will increase our understanding of the molecular and cellular processes involved and provide new biomarkers that may facilitate diagnosis, risk stratification, and monitoring recurrences of $\operatorname{ESCC}(8,9)$.

The transmembrane adherens junctions-associated protein-1 (AJAP1) targets the basolateral membrane of polarized epithelial cells and interacts with E-cadherincatenin complexes of adherens junctions (10). The locus encoding AJAP1 resides in chromosome 1p36 and is frequently deleted from the genomes of various tumor cells 
or is epigenetically silenced, indicating that AJAP1 acts as a tumor suppressor (11-13). Although AJAP1 is involved in cell-cell and cell-extracellular matrix interactions potentially involved in the motility, migration, and invasion of glioblastoma cells $(11,14)$, little evidence is available on its role in oncogenesis. To our knowledge, there are no studies of the expression and regulatory mechanisms of $A J A P 1$ transcription in gastrointestinal cancers, including ESCC. To address these issues, we analyzed ESCC cell lines and tumor tissues to evaluate $A J A P l$ expression and its regulatory mechanisms. Our results indicate that $A J A P 1$ expression levels provide a potential clinical biomarker of the progression and recurrence of ESCC.

\section{Materials and methods}

Sample collection. Nine ESCC cell lines (TE1, TE2, TE3, NUEC1, NUEC2, NUEC3, TT, TTn and WSSC) and a control nontumorigenic epithelial cell line (FHs74) were obtained from the American Type Culture Collection (ATCC; Manassas, VA, USA), the Japanese Collection of Research Bioresources Cell Bank (Osaka, Japan), or were established in our institute. Cells were stored at $-80^{\circ} \mathrm{C}$ using cell preservative solution (Cell Banker; Mitsubishi Chemical Medience Co., Tokyo, Japan) and cultured in RPMI-1640 (Sigma-Aldrich, St. Louis, MO, USA) supplemented with $10 \%$ fetal bovine serum and in an atmosphere containing $5 \% \mathrm{CO}_{2}$ at $37^{\circ} \mathrm{C}(15,16)$. Seventy-eight primary ESCC tissues and adjacent normal tissues were acquired from patients who underwent radical esophageal resection at Nagoya University Hospital between December 2001 and October 2013. All tissue samples were diagnosed histologically as ESCC, frozen immediately after resection, and stored at $-80^{\circ} \mathrm{C}$. None of the patients underwent preoperative treatment such as chemotherapy and radiation. Specimens were classified histologically using the seventh edition of the UICC staging system for esophageal cancer.

Patients were questioned to determine their levels of alcohol consumption, and excessive alcohol consumption was defined as $>210 \mathrm{~g} /$ week for $\geq 3$ years $(2,17)$. The mean age of the 78 patients was $64.9 \pm 8.2$ years (mean \pm standard deviation; range, 44-82 years). The male-to-female ratio was 62:16. Nine, 29, 30 and 10 patients were in stages I, II, III and IV, respectively, according to the UICC staging system (seventh edition). The median duration of patient follow-up was 73.7 months (range, 5.3-149 months) or until death. Postoperative follow-up examinations included physical examination, measurement of serum tumor markers every 3 months, and enhanced computed tomography of the chest and abdominal cavity every 6 months. Adjuvant chemotherapy was administered to selected patients according to the patient's condition and the physician's discretion.

The present study conforms to the ethical guidelines of the World Medical Association Declaration of Helsinki: Ethical Principles for Medical Research Involving Human Subjects. Written informed consent for use of clinical samples and data was required by the Institutional Review Board at Nagoya University, Japan and was obtained from all patients (18).

Analysis of the nucleotide sequences flanking the AJAPI transcription initiation site. Nucleotide sequence analysis was conducted to determine the presence of $\mathrm{CpG}$ islands around the promoter region of $A J A P 1 . \mathrm{CpG}$ islands were defined as follows: $\geq 200$-bp region with a $\mathrm{GC}$ content $>50 \%$ and CpG:expected $\mathrm{CpG} \geq 0.6$ identified using $\mathrm{CpG}$ Island Searcher software (http://cpgislands.usc.edu/) (19-21).

Methylation-specific polymerase chain reaction (MSP-PCR) and 5-aza-2'-deoxycytidine (5-aza-dC) treatment. Genomic DNA samples from 10 cell lines were subjected to bisulfite treatment, and MSP-PCR was conducted to determine the presence or absence of hypermethylation of the AJAPI promoter. To evaluate the influence of promoter hypermethylation on $A J A P 1$ transcription, ESCC cells $\left(1.5 \times 10^{6}\right)$ were treated with $10 \mu \mathrm{M}$ of the DNA methylation inhibitor 5-aza-dC (Sigma-Aldrich) and cultured for 6 days with medium changes on days 1,3 and 5 .

Bisulfite sequence analysis. Genomic DNAs of ESCC cell lines treated with bisulfite were sequenced to verify the accuracy of the MSP-PCR results. After PCR amplification using specific primers (Table I), PCR products were subcloned into a TA cloning vector (Invitrogen, Carlsbad, CA, USA). The DNAs were mixed with $3 \mathrm{ml}$ of a specific primer (M13) and $4 \mathrm{ml}$ of Cycle Sequence mix (ABI PRISM Terminator v1.1 Cycle Sequencing kit; Applied Biosystems, Foster City, CA, USA). Sequence analysis was conducted using an Applied Biosystems ABI310, and sequence electropherograms were generated using ABI Sequence Analysis 3.0 software (Applied Biosystems) (22).

Quantitative real-time reverse transcription-PCR ( $q R T$ $P C R$ ). The levels of AJAPl mRNA were determined using qRT-PCR. Total RNA $(10 \mu \mathrm{g})$ isolated from cell lines, 78 primary ESCCs, and adjacent normal tissues were used as templates for cDNA synthesis. Glyceraldehyde 3-phosphate dehydrogenase $(G A P D H)$ mRNA levels (TaqMan, GAPDH Control Reagents; Applied Biosystems) were quantified to normalize expression levels. qRT-PCR was performed using the SYBR-Green PCR Core Reagents kit (Applied Biosystems) as follows: one cycle at $95^{\circ} \mathrm{C}$ for $10 \mathrm{~min}, 40$ cycles at $95^{\circ} \mathrm{C}$ for $5 \mathrm{sec}$, and $60^{\circ} \mathrm{C}$ for $60 \mathrm{sec}$. All samples were tested in triplicate, and samples without template were included in each PCR plate as negative controls. Real-time detection of SYBR-Green fluorescence was conducted using an ABI StepOnePlus Real-Time PCR system (Applied Biosystems). The expression level of each sample is shown as the value of the AJAPI amplicon divided by that of $G A P D H(23,24)$. To identify cell adhesion molecules that may interact with AJAP1, 10 cell lines were analyzed using qRT-PCR to determine the expression levels of the ezrin $(E Z R)$, focal adhesion kinase $(F A K)$, SRC (SRC), and dihydropyrimidinase-like 3 (DPYSL3) genes $(18,25,26)$. Primers specific for AJAP1, GAPDH, EZR, FAK, SRC, and DPYSL3 are listed in Table I.

Copy number analysis. AJAPI copy numbers of 10 cell lines were determined using TaqMan Copy Number Assays (Applied Biosystems). Twenty nanograms of genomic DNA was amplified using specific primer pairs according to the manufacturer's instructions. Two assays were employed 
Table I. Primers and annealing temperature.

\begin{tabular}{|c|c|c|c|c|c|}
\hline Gene & Experiment & Type & Sequence $\left(5^{\prime}-3^{\prime}\right)$ & $\begin{array}{l}\text { Product } \\
\text { size (bp) }\end{array}$ & $\begin{array}{c}\text { Annealing } \\
\text { temperature }\left({ }^{\circ} \mathrm{C}\right)\end{array}$ \\
\hline \multirow[t]{8}{*}{$A J A P 1$} & \multirow[t]{2}{*}{ qRT-PCR } & Forward & GTTAGCACAACGGAGCCTTC & \multirow[t]{2}{*}{105} & \multirow[t]{2}{*}{60} \\
\hline & & Reverse & GATGATCTGATGGACAGCCA & & \\
\hline & \multirow[t]{2}{*}{ MSP } & Forward & GGTCGCGAGTTTCGCGTTTC & \multirow[t]{2}{*}{184} & \multirow[t]{2}{*}{64} \\
\hline & & Reverse & CCGATCTCCGACTCTCGATC & & \\
\hline & \multirow[t]{2}{*}{ U-MSP } & Forward & GTGTTGATTGGTGGTGGAGT & \multirow[t]{2}{*}{152} & \multirow[t]{2}{*}{64} \\
\hline & & Reverse & TCCCAACACACAACTCTTAC & & \\
\hline & \multirow[t]{2}{*}{ Bisulfite sequencing } & Forward & GTTTTTAGGATTTAGGTGAG & \multirow[t]{2}{*}{316} & \multirow[t]{2}{*}{60} \\
\hline & & Reverse & СТАСТААСТССТААААСТАС & & \\
\hline \multirow[t]{2}{*}{$S R C$} & \multirow[t]{2}{*}{ qRT-PCR } & Forward & CTGACCGCATGGACCGT & \multirow[t]{2}{*}{107} & \multirow[t]{2}{*}{58} \\
\hline & & Reverse & AAGCCAACCTGTCACTTGGTA & & \\
\hline \multirow[t]{2}{*}{$E Z R$} & \multirow[t]{2}{*}{ qRT-PCR } & Forward & GATAGTCGTGTTTTCGGGGA & \multirow[t]{2}{*}{91} & \multirow[t]{2}{*}{60} \\
\hline & & Reverse & CTCTGCATCCATGGTGGTAA & & \\
\hline \multirow[t]{2}{*}{ FAK } & \multirow[t]{2}{*}{ qRT-PCR } & Forward & GCCAAAAGGATTTCTAAACCAG & \multirow[t]{2}{*}{110} & \multirow[t]{2}{*}{64} \\
\hline & & Reverse & CCTGGTCCACTTGATCAGCTA & & \\
\hline \multirow[t]{2}{*}{ DPYSL3 } & \multirow[t]{2}{*}{ qRT-PCR } & Forward & AGAAGAAGGAGGGAGGGAGC & \multirow[t]{2}{*}{110} & \multirow[t]{2}{*}{60} \\
\hline & & Reverse & СТCССTTGATAAGGAGACGG & & \\
\hline \multirow[t]{3}{*}{ GAPDH } & \multirow[t]{3}{*}{ qRT-PCR } & Forward & GAAGGTGAAGGTCGGAGTC & \multirow[t]{3}{*}{226} & \multirow[t]{3}{*}{60} \\
\hline & & Probe & CAAGCTTCCCGTTCTCAGCC & & \\
\hline & & Reverse & GAAGATGGTGATGGGATTTC & & \\
\hline
\end{tabular}

AJAP1, adherens junctions associated protein 1; SRC, cellular SRC; EZR, ezrin; FAK, focal adhesion kinase; DPYSL3, dihydropyrimidinase-like 3; GAPDH, glyceraldehyde 3-phosphate dehydrogenase; qRT-PCR, quantitative real-time reverse-transcription polymerase chain reaction; MSP, methylation specific PCR; U-MSP, un-methylation specific PCR.

as follows: upstream (assay ID Hs04540488_cn, chromosome 1, map position 4798221 in AJAPl intron 2) and downstream (assay ID Hs01575789_cn, chromosome 1, map position 4834502 in the intron 4 to exon 5 of AJAPl gene). Data were analyzed using CopyCaller software (Invitrogen Life Technologies, Carlsbad, CA, USA). Copy number loss was defined as the copy number value equal to 1 determined in the regions upstream, downstream, or both of the AJAPl loci.

Statistical analysis. Correlations between the levels of AJAPI mRNA with those of EZR, FAK, SRC, and DPYSL3 were analyzed using the Spearman's rank correlation test. Differences in the levels of $A J A P 1$ mRNA between ESCC and adjacent normal tissues were analyzed using the Mann-Whitney test. The $\chi^{2}$ test was used to analyze the significance of the association between the expression levels of AJAPI and clinicopathological parameters. Overall and disease-free survival rates were calculated using the Kaplan-Meier method, and the difference in survival curves was analyzed using the log-rank test. We performed multivariate regression analysis using the Cox proportional hazards model to identify prognostic factors, and variables with P-values $<0.05$ were entered into the final model. Statistical analyses were performed using JMP 10 software (SAS Institute, Inc., Cary, NC, USA). P<0.05 was considered statistically significant.

\section{Results}

Expression, methylation, and copy number analysis of cell lines. AJAP1 harbors a CpG island (length 3305 bases, $70.3 \%$ $\mathrm{GC}$, and Observed $\mathrm{CpG}$ :Expected $\mathrm{CpG}=0.883$ ) flanking the transcription initiation site (Fig. 1A). AJAPl mRNA expression levels differed among the nine ESCC cell lines, and five expressed levels $<50 \%$ of that of the control FHs 74 cells (Fig. 1B). MSP-PCR detected methylation of the DNAs of NUEC2, TE1, TE2, and TTn cells, which expressed reduced levels of AJAP1 mRNA. When we compared the levels of $A J A P 1$ mRNA in ESCC cell lines before and after demethylation, reactivation of $A J A P 1$ transcription was detected in cells with complete methylation of $A J A P 1$ before treatment with 5-aza-dC. Moreover, there was no detectable loss of copy number in ESCC cell lines and FHs74 cells (Fig. 1B).

Bisulfite sequence analysis. Sequence analysis revealed that all CpG sites in TTn DNA (complete methylation) were CG (cytosine and guanine) and that the corresponding positions in NUEC1 DNA (absence of methylation) were TG (thymine and guanine) (Fig. 2). These results confirm the MSP-PCR results.

Analysis of the levels of AJAP1 $m R N A$ and those representing potentially interacting molecules. We evaluated the expression levels of genes encoding other cell adhesion molecules that 
A

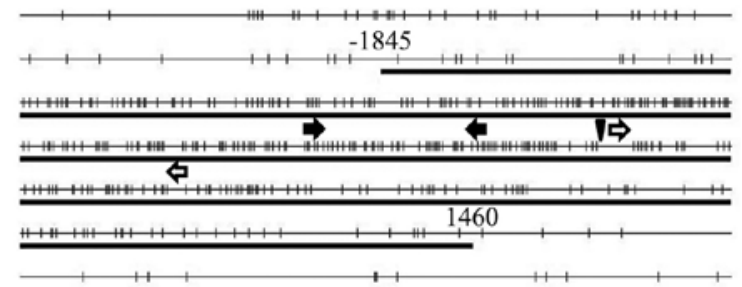

I Transcription start site

$\Rightarrow$ Primers for MSP

$\Rightarrow$ Primers for bisulfite sequencing

CpG island (length 3305 bp)

B

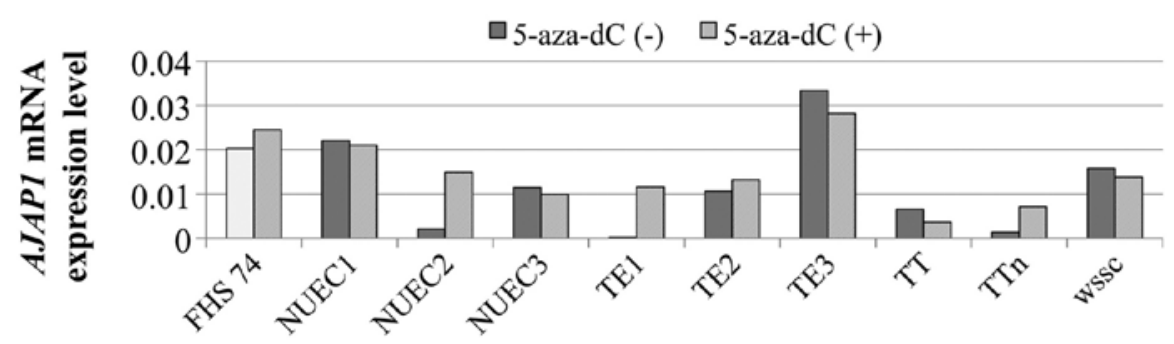

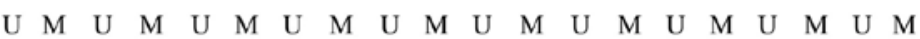

\begin{tabular}{|c|c|c|c|c|c|c|c|c|c|c|c|}
\hline AJAP1 & 1 MSP & & & & & & - & & & & \\
\hline & Methylation & $\mathrm{U}$ & $\mathrm{U}$ & $\mathrm{M}$ & $\mathrm{U}$ & $\mathrm{M}$ & $\mathrm{pM}$ & $\mathrm{U}$ & $\mathrm{U}$ & M & $\mathrm{U}$ \\
\hline & upstream & 2 & 2 & 2 & 2 & 2 & 2 & 2 & 2 & 2 & 2 \\
\hline & downstream & 2 & 2 & 2 & 2 & 2 & 2 & 2 & 2 & 2 & 2 \\
\hline
\end{tabular}

Figure 1. (A) The $\mathrm{CpG}$ island (indicated by the underline) is centered on the $A J A P 1$ transcription initiation site and extends upstream into the promoter region. (B) AJAP1 mRNA levels in control FHs74 cells and nine ESCC cell lines before and after 5-aza-dC treatment. The methylation and copy number of AJAP1 in the 10 cell lines are shown below the graph. M, methylated; pM, partially methylated; $\mathrm{U}$, unmethylated.

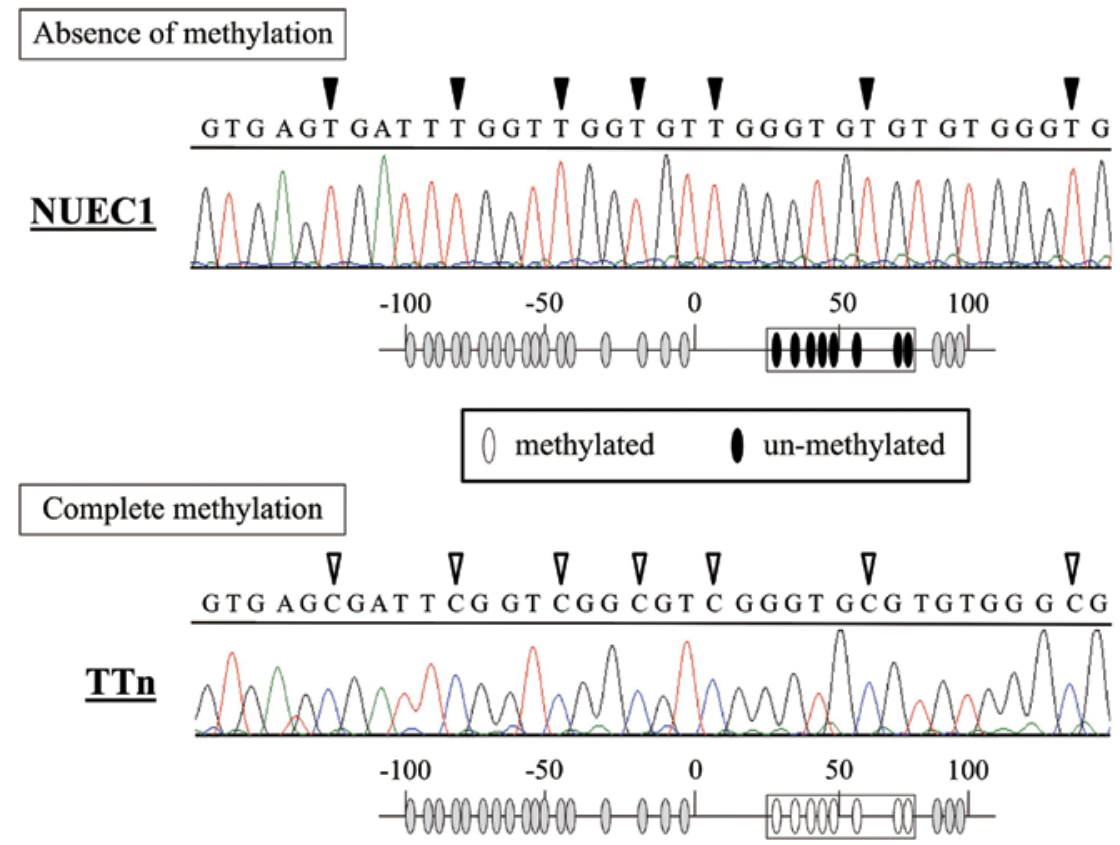

Figure 2. Representative results of bisulfite sequence analysis. All CpG sites in NUEC1 cells were converted to TG, and those of TTn were CG.

may functionally interact with $A J A P 1$. The relative expression levels of EZR, FAK, SRC, DPYSL3, and AJAP1 mRNAs in the ESCC and FHs74 cell lines are shown in Fig. 3A. The AJAPI mRNA levels correlated inversely with those of EZR (correlation coefficient $-0.661, \mathrm{P}=0.038$ ), and there was no significant correlation with the levels of $F A K, S R C$ and DPYSL3 mRNAs (Fig. 3B).
Clinical significance of AJAP1 $\mathrm{mRNA}$ levels. In resected samples, AJAPl mRNA levels were lower in ESCC tissues compared with those of adjacent normal tissues in 67 (86\%) of 78 patients. AJAPl mRNA levels gradually decreased according to the UICC stage (Fig. 4A). The AJAPl mRNA levels of 45 patients with ESCC were less than half of those of adjacent normal tissues, and these patients were 


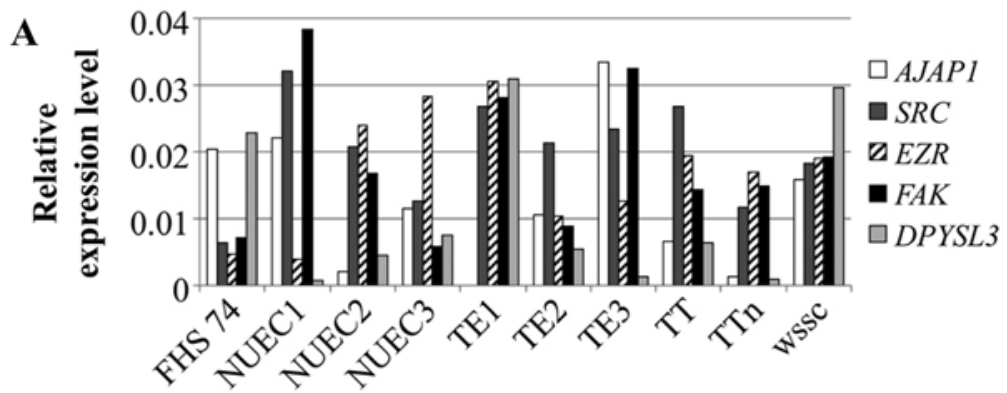

B
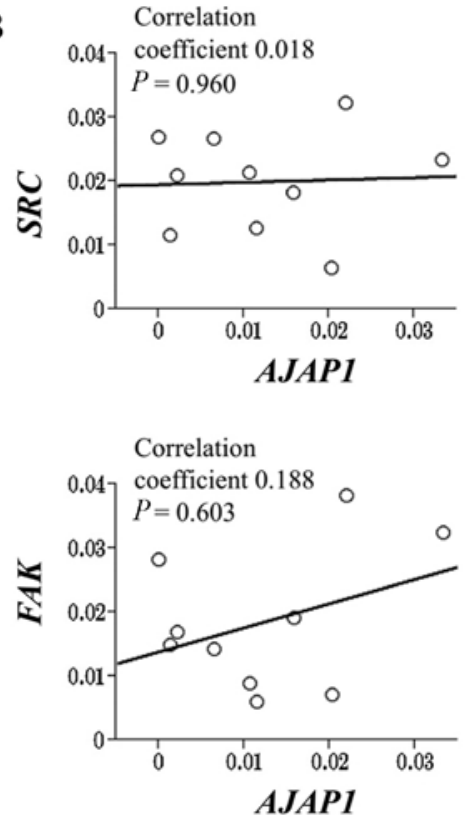
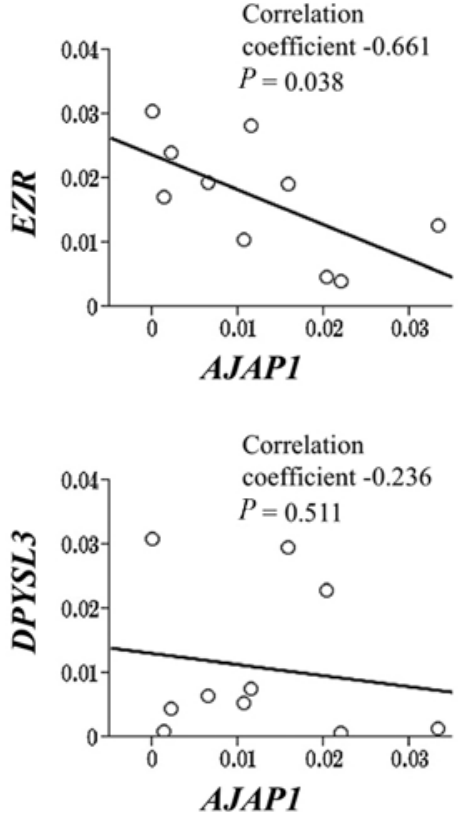

Figure 3. (A) The graph indicates the relative levels of AJAP1, SRC, EZR, FAK, and DPYSL3 mRNAs in control FHs74 cells and nine ESCC cell lines. (B) Relation of mRNA levels between AJAPI and those of SRC,EZR, FAK and DPYSL3.

designated as the 'downregulated AJAP1 transcription' group in the following analyses. Downregulation of AJAPI transcription associated significantly with male individuals but not with clinicopathological factors (Table II). Patients with downregulated $A J A P 1$ transcription were more likely to experience shorter overall survival compared with that of other patients (5-year survival rates were 40 and $66 \%$, respectively; $\mathrm{P}=0.046$ ) (Fig. $4 \mathrm{~B}$ ). Moreover, the disease-free survival of patients with downregulated AJAPl transcription was significantly shorter compared with those of other patients (3-year survival rates were 37 and 64\%, respectively; $\mathrm{P}=0.009$ ) (Fig. 4C). Multivariate analysis of disease-free survival identified downregulated $A J A P I$ transcription as an independent prognostic factor (hazard ratio 2.04 , 95\% confidence interval (CI), 1.11-3.90; $\mathrm{P}=0.022$ ) (Table III).

\section{Discussion}

Despite numerous and intensive recent studies devoted to improving the treatment of esophageal cancer, clinical outcomes remain unsatisfactory as indicated dramatically by 5 -year survival rates of 49.3 and $2.8 \%$ for localized and metastatic disease, respectively $(1,27)$. To develop novel treatment options for ESCC, molecular biological approaches were applied to identify specific molecular diagnostic markers and therapeutic targets (28). We decided to study AJAPl for this purpose, because it encodes a transmembrane protein of adherens junctions in epithelial cells that plays pivotal roles in cell growth and migration and is involved in the pathogenesis of glioblastoma $(11,13)$.

Here, we determined the levels of $A J A P 1$ expression in patients with ESCC to determine the underlying regulatory mechanism. We detected reduced levels of AJAP1 mRNA in 78 and $86 \%$ of ESCC cell lines and resected ESCC tissues, respectively, and the loss of $A J A P 1$ expression correlated with methylation of the $A J A P l$ promoter region without loss of copy number. Moreover, $A J A P 1$ transcription was restored when ESCC cell lines were treated with 5-aza-dC. Downregulation of $A J A P 1$ was associated with worse patient outcomes, particularly postoperative recurrence. The present study shows that the levels of $A J A P 1$ mRNA were frequently decreased in ESCC cell lines and tissues, indicating that AJAP1 plays a role in the pathogenesis of ESCC.

In the ESCC cell lines, differentially expressed AJAPI mRNA, and AJAPI promoter hypermethylation were detected only in cells with significantly decreased $A J A P 1$ mRNA levels. Further, AJAPI mRNA levels were increased in cells treated with a DNA methylation inhibitor, indicating that promoter hypermethylation is a pivotal regulatory mechanism of AJAPI transcription, which is consistent with studies of patients with 
A

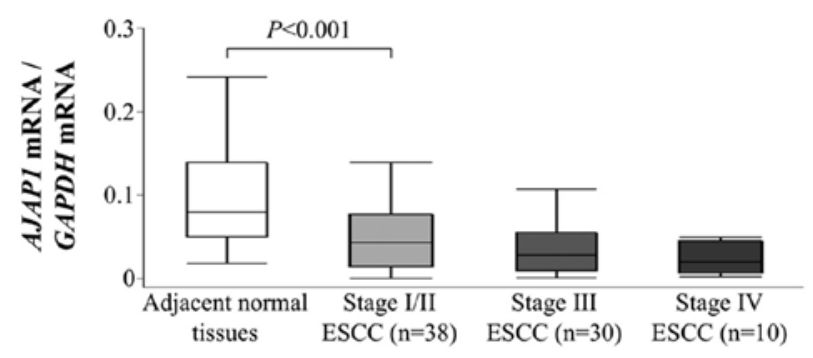

B

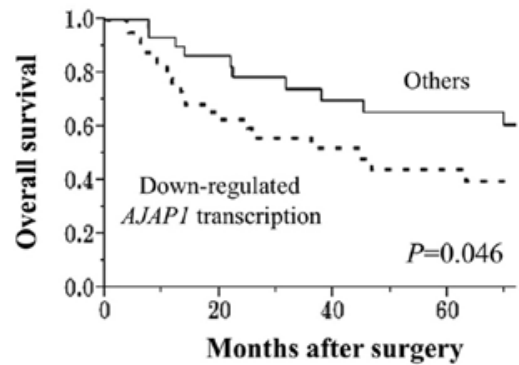

\begin{tabular}{lcccc} 
No. at risk & \multicolumn{4}{c}{ Months after surgery } \\
Others & 33 & 23 & 17 & 16 \\
Down-regulated $A J A P 1$ transcription & 45 & 24 & 15 & 11
\end{tabular}

C

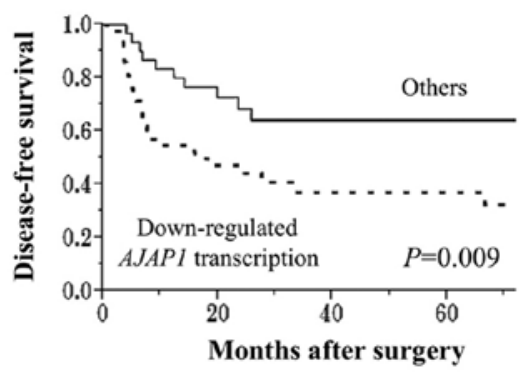

No. at risk

Others

33

Down-regulated $A J A P I$ transcription 45

Figure 4. (A) A stepwise decrease in AJAP1 mRNA levels in ESCC tissues was observed with increasing UICC stage. (B) Patients with downregulated $A J A P 1$ transcription experienced significantly shorter overall survival compared with other patients. (C) Disease-free survival was significantly shorter in patients with downregulated $A J A P 1$ transcription compared with other patients.

glioma $(11,14,29,30)$. In contrast, we identified some ESCC cells with reduced expression of AJAP1 mRNA without DNA methylation, leading us to assume that other mechanisms regulate $A J A P 1$ transcription, such as loss of heterozygosity ( $\mathrm{LOH}$ ), because $A J A P 1$ resides within chromosome 1p36, a known hotspot of chromosomal alterations $(13,31,32)$. However, we did not detect a loss of AJAPI copy number in ESCC cell lines. Because copy number analysis addressed a limited region of the AJAP1 locus, further investigations, including detection of LOH and epigenetic modifications other than DNA methylation are required.

In the present study, we determined the relative levels of mRNAs encoding selected cell adhesion molecules to identify novel proteins that may interact with AJAP1 in ESCC cells. Thus, cell adhesion molecules act coordinately to mediate the migration and invasion of tumor cells (33). We found that the levels of AJAPI mRNA correlated significantly with those of EZR in ESCC and FHs74 cell lines. EZR is a member of the ezrin-radixin-moesin family and acts as a cross-linker between the plasma membrane
Table II. Association between the expression of AJAP1 mRNA and clinicopathological parameters of 78 patients with squamous cell carcinoma of the esophagus.

Clinicopathological Downregulated AJAP1 parameters transcription (n) Other (n) P-value

\begin{tabular}{lrl}
\hline $\begin{array}{l}\text { Age (years) } \\
<65\end{array}$ & 24 & 17 \\
$\geq 65$ & 21 & 16 \\
Gender & & \\
$\quad$ Male & 40 & 22 \\
Female & 5 & 11 \\
Preoperative & & \\
symptoms & & \\
Absent & 8 & \\
Present & 37 & \\
Brinkman index & & \\
$<1,000$ & 23 & \\
$\geq 1,000$ & 22 &
\end{tabular}

0.874

17

16

$0.016^{\mathrm{a}}$

22

11

0.705

7

26

0.167

Excessive alcohol

consumption

Absent
Present
CEA $(\mathrm{ng} / \mathrm{ml})$
$\leq 5$
$>5$
$\mathrm{SCC}(\mathrm{ng} / \mathrm{ml})$
$\leq 1.5$
$>1.5$

9 9

$36 \quad 24$

$42 \quad 28$

35

$27 \quad 24$

$18 \quad 9$

Tumor size (cm)

$<5.0$

$20 \quad 16$

$\geq 5.0 \quad 25$

17

UICC T factor

0.838

T1-2 16

11

T3-4

29

0.961

Tifferentiation

Moderate to well 38

Poor

28

5

involvement

$\begin{array}{lll}\text { Absent } & 10 & 10\end{array}$

Present 35

23

Vessel invasion

0.898

Absent 28

Present 17

21

Intraepithelial spread

Absent

12

Present

13

20

Lymph node

metastasis

$\begin{array}{lll}\text { Absent } & 24 & 20 \\ \text { Present } & 21 & 13\end{array}$

$\chi^{2}$ test. ${ }^{\text {aS }}$ Statistically significant $(\mathrm{P}<0.05)$. CEA, carcinoembryonic antigen; SCC, squamous cell carcinoma-related antigen; UICC, Union for International Cancer Control. 
Table III. Prognostic factors for disease-free survival of 78 patients with squamous cell carcinoma of the esophagus.

\begin{tabular}{|c|c|c|c|c|c|c|c|}
\hline \multirow[b]{2}{*}{ Variable } & \multirow[b]{2}{*}{$\mathrm{n}$} & \multicolumn{3}{|c|}{ Univariate } & \multicolumn{3}{|c|}{ Multivariate } \\
\hline & & Hazard ratio & $95 \% \mathrm{CI}$ & P-value & Hazard ratio & $95 \% \mathrm{CI}$ & P-value \\
\hline Age $(\geq 65)$ & 37 & 1.70 & $0.87-3.35$ & 0.119 & & & \\
\hline Gender (male) & 62 & 2.69 & $1.06-9.06$ & 0.035 & 1.86 & $0.70-6.45$ & 0.227 \\
\hline Preoperative symptoms & 63 & 1.29 & $0.60-3.20$ & 0.541 & & & \\
\hline Brinkman index $(\geq 1,000)$ & 33 & 1.61 & $0.83-3.12$ & 0.153 & & & \\
\hline Excessive alcohol consumption & 60 & 0.99 & $0.47-2.32$ & 0.975 & & & \\
\hline $\mathrm{CEA}(>5 \mathrm{ng} / \mathrm{ml})$ & 8 & 1.38 & $0.47-3.25$ & 0.521 & & & \\
\hline $\mathrm{SCC}(>1.5 \mathrm{ng} / \mathrm{ml})$ & 27 & 0.80 & $0.37-1.61$ & 0.539 & & & \\
\hline Tumor size $(\geq 5.0 \mathrm{~cm})$ & 42 & 1.20 & $0.62-2.31$ & 0.591 & & & \\
\hline UICC T factor (T3-4) & 51 & 1.60 & $0.79-3.48$ & 0.197 & & & \\
\hline Tumor differentiation (poor) & 12 & 1.75 & $0.74-3.67$ & 0.186 & & & \\
\hline Lymphatic involvement & 58 & 5.18 & $1.85-21.5$ & $<0.001$ & 4.37 & $1.38-19.4$ & $0.011^{\mathrm{a}}$ \\
\hline Vessel invasion & 29 & 1.89 & $0.97-3.66$ & 0.062 & 1.39 & $0.70-2.76$ & 0.346 \\
\hline Intraepithelial spread & 33 & 1.02 & $0.52-1.97$ & 0.951 & & & \\
\hline Lymph node metastasis & 34 & 1.92 & $0.95-4.18$ & 0.069 & 1.01 & $0.43-2.08$ & 0.973 \\
\hline Downregulated $A J A P 1$ transcription & 45 & 2.53 & $1.26-5.51$ & 0.009 & 2.19 & $1.07-4.90$ & $0.032^{\mathrm{a}}$ \\
\hline
\end{tabular}

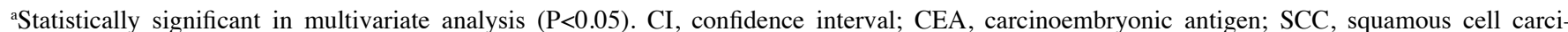
noma-related antigen; UICC, Union for International Cancer Control. Univariate analysis was performed using the log-rank test. Multivariate analysis was performed using the Cox proportional hazards model.

and the actin cytoskeleton (34). Inactive EZR is located in the cytoplasm, and its C-terminal domain, an F-actin-binding site, is masked by the EZR N-terminal domain or those of other ERM proteins (35). Moreover, EZR is a key signaling molecule that is involved in a wide variety of cellular processes such as cell adhesion, survival, and motility as well as signal transduction $(36,37)$. Moreover, EZR contributes to tumorigenesis, development, invasion, and metastasis, likely through regulation of adhesion molecules and signaling to other cell membrane channels in tumors, including ESCC (38-40). Further, the AKT/EZR/NF- $\kappa$ B signaling pathway regulates the epidermal growth factor-induced epithelial-mesenchymal transition (EMT) in squamous cell carcinoma of the tongue (41). Our present results indicate a possible interaction between AJAP1 and EZR that may provide the first step required to understand the role of AJAP1 in oncogenesis. Further investigation of the correlation between the expression of AJAP1 and EMT-associated molecules are required.

We show here that AJAPl mRNA levels gradually decreased as a function of UICC tumor stage, highlighting the diagnostic implications of analyzing AJAPI expression in esophageal tissues. Downregulation of AJAP1 mRNA in ESCC tissues associated significantly with worse prognosis after curative esophagectomy, particularly with disease-free survival. This finding emphasizes that $A J A P 1$ expression is a potential biomarker for patients with ESCC who are susceptible to recurrence.

Taken together, our analyses of $A J A P 1$ promise to improve clinical management of ESCC as follows: i) The expression levels of $A J A P 1$ in biopsy tissue obtained using endoscopic surveillance may identify patients requiring intensive systemic treatment or neoadjuvant therapy; ii) the expression levels of AJAPI in surgical specimens may predict recurrence and subsequent adverse prognosis, leading to the design of appropriate therapeutic strategies; and iii) demethylating agents targeting AJAPl may serve as therapeutics. However, this study is limited by its lack of direct functional analysis of AJAP1, and we are unable to conclude that AJAP1 acts a suppressor of ESCC. Further, the mechanisms that regulate $A J A P 1$ expression, other than promoter hypermethylation, remain to be determined. Further studies are therefore necessary to identify the molecular mechanisms underlying the phenotypes of ESCC cells.

In summary, our data suggest that $A J A P l$ expression is frequently suppressed in ESCC and that hypermethylation of the $A J A P 1$ promoter region is a pivotal regulatory mechanism of $A J A P 1$ expression in ESCC. Downregulation of AJAPl in ESCC tissues may represent a promising biomarker for predicting ESCC recurrence.

\section{References}

1. Siegel R, Naishadham D and Jemal A: Cancer statistics, 2012. CA Cancer J Clin 62: 10-29, 2012.

2. Oya H, Kanda M, Takami H, Hibino S, Shimizu D, Niwa Y, Koike M, Nomoto S, Yamada S, Nishikawa Y, et al: Overexpression of melanoma-associated antigen D4 is an independent prognostic factor in squamous cell carcinoma of the esophagus. Dis Esophagus 28: 188-195, 2015.

3. Enzinger PC and Mayer RJ: Esophageal cancer. N Engl J Med 349: 2241-2252, 2003.

4. Mayne ST and Navarro SA: Diet, obesity and reflux in the etiology of adenocarcinomas of the esophagus and gastric cardia in humans. J Nutr 132 (Suppl): 3467S-3470S, 2002.

5. Kamangar F, Chow WH, Abnet CC and Dawsey SM: Environmental causes of esophageal cancer. Gastroenterol Clin North Am 38: 27-57, vii, 2009. doi: 10.1016/j.gtc.2009.01.004. 
6. Song Y, Li L, Ou Y, Gao Z, Li E, Li X, Zhang W, Wang J, Xu L, Zhou Y, et al: Identification of genomic alterations in oesophageal squamous cell cancer. Nature 509: 91-95, 2014.

7. Tang JC, Lam KY, Law S, Wong J and Srivastava G: Detection of genetic alterations in esophageal squamous cell carcinomas and adjacent normal epithelia by comparative DNA fingerprinting using inter-simple sequence repeat PCR. Clin Cancer Res 7: $1539-1545,2001$

8. Hibino S, Kanda M, Oya H, Takami H, Shimizu D, Nomoto S, Hishida M, Niwa Y, Koike M, Yamada S, et al: Reduced expression of DENND2D through promoter hypermethylation is an adverse prognostic factor in squamous cell carcinoma of the esophagus. Oncol Rep 31: 693-700, 2014.

9. Oya H, Kanda M, Koike M, Iwata N, Niwa Y, Shimizu D, Takami H, Sueoka S, Hashimoto R, Ezaka K, et al: Detection of serum melanoma-associated antigen D4 in patients with squamous cell carcinoma of the esophagus. Dis Esophagus: May 8, 2015 (Epub ahead of print). doi: 10.1111/dote.12373.

10. Schreiner A, Ruonala M, Jakob V, Suthaus J, Boles E, Wouters F and Starzinski-Powitz A: Junction protein shrew-1 influences cell invasion and interacts with invasion-promoting protein CD147. Mol Biol Cell 18: 1272-1281, 2007.

11. Han L, Zhang KL, Zhang JX, Zeng L, Di CH, Fee BE, Rivas M, Bao ZS, Jiang T, Bigner D, et al: AJAP1 is dysregulated at an early stage of gliomagenesis and suppresses invasion through cytoskeleton reorganization. CNS Neurosci Ther 20: 429-437, 2014.

12. McDonald JM, Dunlap S, Cogdell D, Dunmire V, Wei Q, Starzinski-Powitz A, Sawaya R, Bruner J, Fuller GN, Aldape K, et al: The SHREW1 gene, frequently deleted in oligodendrogliomas, functions to inhibit cell adhesion and migration. Cancer Biol Ther 5: 300-304, 2006.

13. Lin N, Di C, Bortoff K, Fu J, Truszkowski P, Killela P, Duncan C, McLendon R, Bigner D, Gregory S, et al: Deletion or epigenetic silencing of $A J A P 1$ on $1 \mathrm{p} 36$ in glioblastoma. Mol Cancer Res 10 208-217, 2012

14. Zeng L, Fee BE, Rivas MV, Lin J and Adamson DC: Adherens junctional associated protein-1: A novel 1p36 tumor suppressor candidate in gliomas (Review). Int J Oncol 45: 13-17, 2014.

15. Kanda M, Shimizu D, Nomoto S, Takami H, Hibino S, Oya $\mathrm{H}$ Hashimoto R, Suenaga M, Inokawa Y, Kobayashi D, et al: Prognostic impact of expression and methylation status of DENN/MADD domain-containing protein 2D in gastric cancer Gastric Cancer 18: 288-296, 2015.

16. Kanda M, Sugimoto H, Nomoto S, Oya H, Hibino S, Shimizu D, Takami H, Hashimoto R, Okamura Y, Yamada S, et al: B cell translocation gene 1 serves as a novel prognostic indicator of hepatocellular carcinoma. Int J Oncol 46: 641-648, 2015.

17. Long MJ, Jiang CQ, Lam TH, Lin JM, Chan YH, Zhang WS, Jin YL, Liu B, Thomas GN and Cheng KK: Alcohol consumption and electrocardiographic left ventricular hypertrophy and mediation by elevated blood pressure in older Chinese men: The Guangzhou Biobank Cohort Study. Alcohol 47: 473-480, 2013.

18. Tanaka Y,Kanda M,Sugimoto H, Shimizu D, Sueoka S, Takami H, Ezaka K, Hashimoto R, Okamura Y, Iwata N, et al: Translational implication of Kallmann syndrome-1 gene expression in hepatocellular carcinoma. Int J Oncol 46: 2546-2554, 2015.

19. Kanda M, Shimizu D, Nomoto S, Hibino S, Oya H, Takami H, Kobayashi D, Yamada S, Inokawa Y, Tanaka C, et al: Clinical significance of expression and epigenetic profiling of TUSC1 in gastric cancer. J Surg Oncol 110: 136-144, 2014.

20. Takai D and Jones PA: The CpG island searcher: A new WWW resource. In Silico Biol 3: 235-240, 2003.

21. Kanda M, Sugimoto H, Nomoto S, Oya H, Shimizu D, Takami H, Hashimoto R, Sonohara F, Okamura Y, Yamada S, et al: Clinical utility of PDSS2 expression to stratify patients at risk for recurrence of hepatocellular carcinoma. Int J Oncol 45: 2005-2012, 2014

22. Kanda M, Nomoto S, Oya H, Hashimoto R, Takami H, Shimizu D, Sonohara F, Kobayashi D, Tanaka C, Yamada S, et al: Decreased expression of prenyl diphosphate synthase subunit 2 correlates with reduced survival of patients with gastric cancer. J Exp Clin Cancer Res 33: 88, 2014.

23. Kanda M, Nomoto S, Oya H, Takami H, Hibino S, Hishida M, Suenaga M, Yamada S, Inokawa Y, Nishikawa Y, et al: Downregulation of DENND2D by promoter hypermethylation is associated with early recurrence of hepatocellular carcinoma. Int J Oncol 44: 44-52, 2014.
24. Kanda M, Oya H, Nomoto S, Takami H, Shimizu D, Hashimoto R, Sueoka S, Kobayashi D, Tanaka C, Yamada S, et al: Diversity of Clinical Implication of B-cell translocation gene 1 expression by histopathologic and anatomic subtypes of gastric cancer. Dig Dis Sci 60: 1256-1264, 2014.

25. Oya H, Kanda M, Sugimoto H, Shimizu D, Takami H, Hibino S, Hashimoto R, Okamura Y, Yamada S, Fujii T, et al: Dihydropyrimidinase-like 3 is a putative hepatocellular carcinoma tumor suppressor. J Gastroenterol 50: 590-600, 2015.

26. Kanda M, Nomoto S, Oya H, Shimizu D, Takami H, Hibino S Hashimoto R, Kobayashi D, Tanaka C, Yamada S, et al: Dihydropyrimidinase-like 3 facilitates malignant behavior of gastric cancer. J Exp Clin Cancer Res 33: 66, 2014.

27. Shim HJ, Shin MH, Kim HN, Kim JH, Hwang JE, Bae WK, Chung IJ and Cho SH: The prognostic significance of FGFR4 Gly388 polymorphism in esophageal squamous cell carcinoma after concurrent chemoradiotherapy. Cancer Res Treat: May 14, 2015 (Epub ahead of print). doi: 10.4143/crt.2015.018

28. Lee HW, Kwon J, Kang MC, Noh MK, Koh JS, Kim JH and Park JH: Overexpression of HSP47 in esophageal squamous cell carcinoma: Clinical implications and functional analysis. Dis Esophagus: May 8, 2015 (Epub ahead of print). doi: $10.1111 /$ dote.12359.

29. Cogdell D, Chung W, Liu Y, McDonald JM, Aldape K, Issa JP, Fuller GN and Zhang W: Tumor-associated methylation of the putative tumor suppressor AJAPI gene and association between decreased $A J A P 1$ expression and shorter survival in patients with glioma. Chin J Cancer 30: 247-253, 2011.

30. Zeng L, Kang C, Di C, Fee BE, Rivas M, Lin J and Adamson DC: The adherens junction-associated protein 1 is a negative transcriptional regulator of MAGEA2, which potentiates temozolomide-induced apoptosis in GBM. Int J Oncol 44: 1243-1251, 2014.

31. Mori T, Nomoto S, Koshikawa K, Fujii T, Sakai M, Nishikawa Y, Inoue $\mathrm{S}$, Takeda $\mathrm{S}$, Kaneko T and Nakao A: Decreased expression and frequent allelic inactivation of the RUNX3 gene at 1p36 in human hepatocellular carcinoma. Liver Int 25: 380-388, 2005.

32. Zhang H, Zhai Y, Hu Z, Wu C, Qian J, Jia W, Ma F, Huang W, Yu L, Yue W, et al: Genome-wide association study identifies 1p36.22 as a new susceptibility locus for hepatocellular carcinoma in chronic hepatitis B virus carriers. Nat Genet 42: 755-758, 2010.

33. Xin M, Dong XW and Guo XL: Role of the interaction between galectin-3 and cell adhesion molecules in cancer metastasis. Biomed Pharmacother 69: 179-185, 2015.

34. Jin T, Jin J, Li X, Zhang S, Choi YH, Piao Y, Shen X and Lin Z: Prognostic implications of ezrin and phosphorylated ezrin expression in non-small cell lung cancer. BMC Cancer 14: 191, 2014.

35. Bretscher A, Edwards K and Fehon RG: ERM proteins and merlin: Integrators at the cell cortex. Nat Rev Mol Cell Biol 3: 586-599, 2002

36. Srivastava J, Elliott BE, Louvard D and Arpin M: Src-dependent ezrin phosphorylation in adhesion-mediated signaling. Mol Biol Cell 16: 1481-1490, 2005.

37. Wang X, Liu M and Zhao CY: Expression of ezrin and moesin related to invasion, metastasis and prognosis of laryngeal squamous cell carcinoma. Genet Mol Res 13: 8002-8013, 2014.

38. Xie JJ, Xu LY, Xie YM, Zhang HH, Cai WJ, Zhou F, Shen ZY and $\mathrm{Li}$ EM: Roles of ezrin in the growth and invasiveness of esophageal squamous carcinoma cells. Int J Cancer 124: 2549-2558, 2009.

39. Kong J, Li Y, Liu S, Jin H, Shang Y, Quan C, Li Y and Lin Z: High expression of ezrin predicts poor prognosis in uterine cervical cancer. BMC Cancer 13: 520, 2013.

40. Ghaffari A, Hoskin V, Szeto A, Hum M, Liaghati N, Nakatsu K, LeBrun D, Madarnas Y, Sengupta S and Elliott BE: A novel role for ezrin in breast cancer angio/lymphangiogenesis. Breast Cancer Res 16: 438, 2014.

41. Wang Y, Lin Z, Sun L, Fan S, Huang Z, Zhang D, Yang Z, Li $J$ and Chen W: Akt/Ezrin Tyr353/NF-kB pathway regulates EGF-induced EMT and metastasis in tongue squamous cell carcinoma. Br J Cancer 110: 695-705, 2014. 